\title{
Bankruptcy of Village-Owned Enterprises Based on Analysis of Various Factors on BUMDes Cipta Werdhi Amerta, Village of Tinga-Tinga, District of Gerokgak, Regency of Buleleng
}

\author{
I Wayan Suwendra ${ }^{1, *}$ I Nyoman Sujana ${ }^{1}$ Kadek Rai Suwena ${ }^{1}$
}

\author{
${ }^{1}$ Department of Economic and Accounting, Universitas Pendidikan Ganesha, Singaraja, Indonesia \\ *Corresponding author. Email: wayan.suwendra@undiksha.ac.id
}

\begin{abstract}
The aim of this research is to find out what internal factors causing the bankruptcy of BUMDes Cipta Amerta, what external factors causing the bankruptcy of BUMDes Cipta Amerta and which factor is more dominant causing the bankruptcy of BUMDes Cipta Werdhi Amerta. This research method is descriptive quantitative with sample of decision makers at the village as well as public figures. Based on the result of analysis it can be said that, respondents state they are agree that the cause of bankruptcy of BUMDes is internal and external factors. Seen from these two factors then it can be stated that internal factor is more dominant causing the bankruptcy of BUMDes compared to external factors. One of those internal factors among others is lacking of business planning. Planning factor indeed is very important, and the first activity being done when running a business. In Implementation of Planning Management Function ranks first when running a business. In addition to business planning factor, bankruptcy is also caused by inefficiency of Business Management factor, corruption carried out by business managers and lack of skill in managing a business. Furthermore, external factor which is the most dominant causing bankruptcy of BUMDes is deterioration of community income, so that it is difficult to return the debt.
\end{abstract}

Keywords: BUMDes, Internal Factors, External Factors.

\section{INTRODUCTION}

Village government has full authority in managing its village so as the village has strategic position as national development pillar. As an independent institution, the village has many potentials not only from the aspect of Human Resources, but also the availability of adequate Natural Resources. If both potencies can be managed well and optimally, then it will provide prosperity to village community. However, we are aware that so far development on village level still has many weaknesses.

Development weakness on village level is due to the problem of inadequate human resources, as well as due to low Village Income. Various efforts has been done by government by disbursing various funds for village development program, one of it is Village-owned Enterprises (BUMDes).

Establishment and management of Village-owned Enterprises (BUMDes).is the manifestation of productive economic management of the village being carried out in cooperative, participatory, emancipation, transparent, accountable and sustainable way, then it needs serious effort to make Enterprise management to run effectively, efficiently, professionally and independent.

Various regulations which regulated regarding the existence of BUMDes in this country is so many starting from the Law No. 32 year 2004 regarding Regional Government Article 213, Government Regulation No. 72 year 2005 regarding Village, Chapter VII section fifth regarding $B U M D e s$, it was stated that this institution was incorporated, next the Law No. 6 year 2014 regarding Village also mentioned about Village-owned Enterprises as business entity that the whole or most of the capital owned by the Village through direct participation stemming from Village wealth which was separated in order to managing asset, services and other business as much as possible for prosperity of village community. And the newest was the issuance of Government Regulation No. 11 year 2021 regarding BUMDes, the 
core of the regulation was that it was justified to make common BUMDes. So many regulations were made to cover BUMDes surely with expectation that BUMDes became stronger. In line with the increase of village fund allocation, BUMDes also is growing. Number of BUMDes grows significantly in which in 2014 only existed 1,022 unit, in 2015 increased by 10 -fold to 12,115 unit [3]. In 2016 became 18,446 unit, in 2017 the number of $B U M D e s$ in Indonesia also experiencing the increase by 4,000 unit to 14,686 unit and in 2019 became 50,199 unit [4].

But unfortunately, fantastic growth of BUMDes is not accompanied with adequate qualities. Secretary General of Ministry of Home Affairs and PDTT Anwar Sanusi stated that from 22,000 BUMDes in 2019, the average was still in the state of developing. Meanwhile for BUMDes included in advanced category nationally numbering only 50 unit $(0.23 \%)$ [5]. Besides that, from data of 50,199 unit of BUMDes until September 2019, the ones which active only numbering 2,146 unit (11.63\%) [6]. Secretary General of Village-owned Enterprises (BUMDes) of Indonesia Rudy Suryanto also mentioned that from 27,067 BUMDes, only around $10 \%$ which its business were running, meanwhile the rest were stuck or some were running but not giving a profit [7].

Similar phenomenon also occurred in Regency of Buleleng, Province of Bali, based on data acquired from Empowerment Office of Community and Village, until 2020 the number of BUMDes in the Regency of Buleleng numbering 127 unit, with status 5 unit in process, 15 unit just established, 14 unit under developed, 24 unit had issues, 64 were developing and 5 unit were the best. Graphically showed in Figure 1. From the data it shows that $26.77 \%$ of BUMDes management were not optimal, and based on that data $19 \%$ had issues.

\section{Existing Condition BUMDes in Regency of Buleleng 2020}

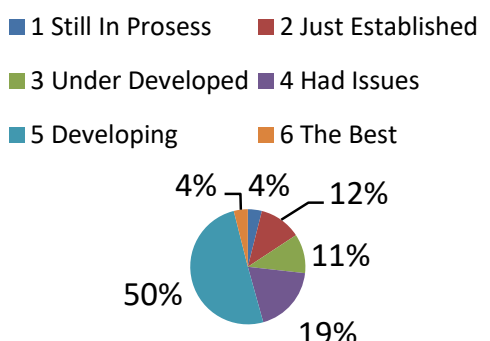

Figure1. Existing Condition BUMDes in Regency of Buleleng 2020

According to (Ali et. al., 2019) stated that factors hindering BUMDes development were budgeting, human resources of the managers and limited support by private parties. In addition they stated that obstacles experienced by most of BUMDes among others were (1) there was no common understanding between stakeholders in the village, (2) did not understand village's authority, (3) did not understand the concept, (4) there was no transparency of public information in the village, (5) there was a corrupt behavior, (6) there was a trauma of failure by village apparatus, (7) weakness of managerial ability, (8) BUMDes did not attract young generation (Millennial group). [8] also stated that the obstacle of BUMDes program implementation in the village also lied on competency of human resource as well as facilities and funding. Besides that, some of BUMDes managers also could not work professionally in managing business unit and considering BUMDes work only as part time job so that human resources was still a main constraint in development and management of BUMDes. The state of having obstacles without any improvement or correction will make BUMDes' problems getting worse that is to become bankrupt.

Issue of bankruptcy has always been a disturbing matter for any party. Bankruptcy of any business creates many problems in economy. The aggrieved party is not only business owners, but also employees, creditors, business partners, as well as public as consumers also will be harmed. Therefore, signs of bankruptcy of any business must be detected early on by management before it is too late and difficult to handle. Bankruptcy is the state when company experiencing inadequate funding to run its business, so that company is not able to continue its operational activities smoothly like before, due to inadequate funding. According to [9], bankruptcy is an uncertainty regarding capability of any company to continue its operational activities if financial condition has decreased.

Bankruptcy is company's failure in running company's operational to gain profit. Bankruptcy is also a condition where company is not able to fulfill its obligation. Various problems faced by BUMDes in Regency of Buleleng is started from Bad Credit, misappropriation of funds by BUMDes management, personal use of funds by Head of BUMDes, and unclear Financial Report which cannot be accounted for. Various efforts have been done to rescue the BUMDes.

From 24 BUMDes which have issues in Regency of Buleleng, one of it is BUMDes Cipta Werdhi Amerta, Village of Tinga-Tinga, District of Gerokgak, Regency of Buleleng. This BUMDes was found since 2012, based on the Decree by the Village Head of Tinge-Tinge No. 6 year 2012 regarding the Founding of Village-owned Enterprises of Tinge-Tinge village. The origin was started with GERBANGSADU (Action to Build the Village in an Integrated manner) Program, program to build the village from Bali province. The manager of this business entity, the Head Gede Edi Sutisna, SE, Secretary Gusti Putu Turya Adryana and Treasurer Komang Dewi 
Apriliani. This business entity has business units among others, Savings and Loan unit, Village's PAM Management, and Saprodi. Initial capital owned by the BUMDes was Rp.800,000. Based on data which sourced from Empowerment Office of Community and Village (PMD) of Regency of Buleleng, profit in the last 2 years was Rp.3,153,165 (year 2019) and next in 2020 was Rp.800,000. This condition showed financial performance of the institution was not healthy.

Based on this secondary data, the researcher wanted to find out what was really happened on BUMDes Cipta Werdhi Amerta, Village of Tinge-Tinge. The field fact was found that BUMDes office was sealed, as seen in the picture on appendix. Next initial observation was conducted to the condition of BUMDes through interview with Village Secretary Mr. Made Heriasa, which he said that condition of BUMDes since 2020 was in condition of not operating anymore. This was due to the debts that could not be collected, there was a mistake in operational management and business management. And ultimately the Management could not take responsibility of its BUMDes management. Based on the background, the research is directed to make Analysis of Factors causing the bankruptcy of BUMDes. Based on the background then the problem formulation is: What factors is causing the bankruptcy of BUMDes Cipta Werdhi Amerta, and what factors are more dominant causing the bankruptcy of BUMDes Cipta Werdhi Amerta.

\section{METHOD}

This research is conducted at BUMDes Cipta Werdhi Amerta, focused on the factors causing the bankruptcy of BUMDes Cipta Werdhi Amerta. This research is descriptive quantitative research. Factors which are suspected to causing bankruptcy of BUMDes Cipta Werdhi Amerta are: (1) internal factors, (2) external factors. The result which is expected from this study is dominant factors causing the bankruptcy of BUMDes Cipta Werdhi Amerta. Type of data being used in this study is quantitative data in the form of numbers in Likert scale of respondents' answers after assessment regarding related questionnaire. Meanwhile in data sampling of this research, data is collected through primary and secondary data source.

Samples which being used in this study are Village apparatus, Public figures, Village Representative body, experts of 35 persons and respondents. Respondent are taken through purposive sampling technique with aims to obtain representative samples based on criteria being set. According to [10], purposive sampling is sample setting technique with certain consideration.

Data sampling method is conducted with the method of interview and questionnaire distribution, and for type of questionnaire being used is closed questionnaire in expanded question through interview. Data obtained from questionnaire is ordinal data, and based on this ordinal data then data analysis is performed.

\section{RESULTS \& DISCUSSION}

Based on Table 1 it can be described that internal factor which is more dominant causing the bankruptcy of BUMDes is lacking of business planning with score of 95, next inefficiency of business management with score of 94, next internal factor is no transparency in business management and corruption committed by business managers with the same score of 91 , next followed by amount of debt which unable to be collected with score 88 , next the lack of skill by business managers, do not have skill to run a business, amount of debt that must be paid, frauds committed by business managers with score of 87 , and the least score is amount of cost that must be spent. Ref [1] stated that in general the cause of bankruptcy could be divided into two namely internal factor and external factor. Viewed from those two factors then it can be stated that internal factors are more dominant causing the bankruptcy of BUMDes compared to external factors. One internal factor among others is lacking of business planning being done. Planning aspect is indeed a very important thing, and the first activity to be done when running a business.

Table 1. Internal factors which causing the bankruptcy of BUMDes Cipta Werdhi Amerta

\begin{tabular}{|l|l|c|}
\hline No & \multicolumn{1}{|c|}{ Internal Factors } & Score \\
\hline 1 & Lack of Business Planning being done & 95 \\
\hline 3 & Inefficiency of Business Management & 94 \\
\hline 4 & Too big cost that must be spent & 81 \\
\hline 5 & $\begin{array}{l}\text { Do not have skill in managing a } \\
\text { business }\end{array}$ & 87 \\
\hline 6 & $\begin{array}{l}\text { No transparency in business } \\
\text { management }\end{array}$ & 81 \\
\hline 7 & $\begin{array}{l}\text { The amount of debt that must be paid } \\
\text { by company }\end{array}$ & 87 \\
\hline 8 & $\begin{array}{l}\text { The amount of debt that unable to be } \\
\text { collected from the debtors }\end{array}$ & 88 \\
\hline 9 & $\begin{array}{l}\text { There are frauds committed by } \\
\text { business managers }\end{array}$ & 91 \\
\hline 10 & $\begin{array}{l}\text { Corruption committed by business } \\
\text { managers }\end{array}$ & \\
\hline
\end{tabular}


Table 2. External factors which causing the bankruptcy of BUMDes Cipta Werdhi Amerta

\begin{tabular}{|c|c|c|}
\hline No & External Factors & Score \\
\hline 1 & $\begin{array}{l}\text { There is a change of needs from clients } \\
\text { (for example, quick, effective and easy } \\
\text { service) }\end{array}$ & 90 \\
\hline 2 & $\begin{array}{l}\text { Clients who did not pay debts or other } \\
\text { loans to the company }\end{array}$ & 90 \\
\hline 3 & $\begin{array}{l}\text { Disharmonious relationship with clients } \\
\text { or did not communicate well with } \\
\text { clients }\end{array}$ & 89 \\
\hline 4 & $\begin{array}{l}\text { Too many debts given to debtors with } \\
\text { long return time }\end{array}$ & 87 \\
\hline 5 & Very tough competition & 83 \\
\hline 6 & Clients switch side to another company & 89 \\
\hline 7 & $\begin{array}{l}\text { Deterioration of public income so that } \\
\text { they felt difficult to pay debts }\end{array}$ & 91 \\
\hline 8 & Loss of community's livelihood & 83 \\
\hline 9 & $\begin{array}{l}\text { Many similar business around it so that } \\
\text { became competitors }\end{array}$ & 87 \\
\hline 10 & $\begin{array}{l}\text { Lack of clients' trust to the company } \\
\text { owned by village }\end{array}$ & 90 \\
\hline
\end{tabular}

Based on Table 2 it can be described that external factor which most dominant causing the bankruptcy of BUMDes is the deterioration of community income so that they feel difficult to pay debts with score of 91 , next there is a change of needs from clients (for example, quick, effective and easy service), clients who did not pay debts or other loans to the company, and lack of clients' trust to the company owned by village, clients switch side to another company with score of 89 , next external factor is too many debts given to debtors with long return time, and many similar business around it so that became competitors with the same score of 87 , next external factor with the least score is very tough competition, and loss of community's livelihood with score of 83 . Finding of this research is in line with opinion by [2] who stated that factor which causing debts could not be collected was job factor (external factor) when people who used to work now became unemployed that causing them unable to pay their debts.

\subsection{Dominant factors which causing the bankruptcy of BUMDes Cipta Werdhi Amerta}

Based on analysis result of dominant factors causing the bankruptcy of BUMDes Cipta Werdhi Amerta, as seen in Table 3.
Table 3. Dominant factors causing the bankruptcy of BUMDes Cipta Werdhi Amerta

\begin{tabular}{|l|l|c|}
\hline No & \multicolumn{1}{|c|}{ External Factors } & Score \\
\hline 1 & Internal Factors & 888 \\
\hline 2 & External Factors & 879 \\
\hline
\end{tabular}

Based on Table 3, it shows that internal factors is more dominant causing the bankruptcy of BUMDes with total score of 888 compared to external factors with total score of 879 . This is in line with opinion by (Ibrahim et. al.,2019), who stated that internal factors were more dominant causing the slow growth of BUMDes.

\section{CONCLUSION}

Internal factor which is the most dominant causing the bankruptcy of BUMDes is the lack of business planning being done, inefficiency of business management, no transparency in business management, corruption committed by business managers, amount of debts unable to collect, next the lack of skill by business managers, do not have skill to run a business, amount of debts that must be paid by company, frauds committed by business managers, and amount of cost that must be spent. External factors are deterioration of community income so that difficult to pay debts, next there is a change of needs from clients (for example, quick, effective and easy service), clients who did not pay debts or other loans to the company, lack of clients' trust to the company owned by village, clients switch side to another company, too many debts given to debtors with long return time, and many similar business around it so that became competitors of the company, very tough competition, and loss of community's livelihood. Dominant factors which causing the bankruptcy of BUMDes is internal factors. Further it can be suggested that in running business activities especially BUMDes, it can be done with good planning. Bankruptcy is more inclined caused by Human Resources factor, so in recruitment of employee or manager must be done selectively.

\section{REFERENCES}

[1] Darsono and Ashari, Practical Guideline to Understand Financial Report. Andi Offset, 2001.

[2] K. A. Wicaksana, N. L. G. E. Sulindawati, and M. A. Prayudi, "Analysis of Factors Causing Bad Credits on BUMDes Karya Bakti Pertiwi, Village of Panji Anom, District of Sukasada, Regency of Buleleng," JIMAT (Scientific J. Account. Students) Undiksha, vol. 8, no. 2, 2018, [Online]. Available: https://doi.org/10.23887/JIMAT.V812.14659 .

[3] KPPOD, "Perkembangan BUMDES," 2019. https://www.kppod.org/peraturan/index?sort=tentang\&page $=2686 \&$ per-page $=5$. 
[4] A. Andini, "21 ribu desa di Indonesia belum memiliki BUMDes," Kabar Desa, 2021. https://desa.lokadata.id/kabardesa?category $=$ BUMDes .

[5] A. Nasrulhaq, "Hingga 2018, 61 Persen Desa di Indonesia Sudah Punya BUMDes," Detik.com, $2019 . \quad$ https://news.detik.com/berita/d4526846/hingga-2018-61-persen-desa-diindonesia-sudah-punya-BUMDes.

[6] A. M. Mubarok, "BUMDes Salah Satu Kunci Penanggulangan Kemiskinan Ekstrem," 2021. https://nasional.sindonews.com/read/573606/15/B UMDes-salah-satu-kunci-penanggulangankemiskinan-ekstrem-1634649014.

[7] S. Huda, "Manajemen BUMDes, Sebuah Pengelolaan Desa Mandiri," Jogja daily, 2021. https://jogjadaily.com/2021/10/manajemenBUMDes-sebuah-pengelolaan-desa-mandiri/.

[8] H. Liow, F. D. Engkong, and N. A. Palar, "IMPLEMENTATION OF MANAGEMENT POLICY OF VILLAGE-OWNED ENTERPRISES AT VILLAGE OF TONDEGESAN DISTRICT OF KAWANGKOAN," PUBLIC Adm. J., vol. 4, no. 61, 2018, [Online]. Available: https://ejournal.unsrat.ac.id/index.php/JAP/article/ view/20731.

[9] R. Lemana and R. Surjanto, Autonomy and Financial Management of Region. Andi Offset, 2003.

[10] Sugiyono, Metode Penelitian Bisnis (Pendekatan Kuantitatif, Kualitatif dan R\&D). Bandung: Alfabeta, 2017. 